\title{
A Short Review on Green Supply Chain Management Practices
}

\author{
The Impact on Operational and Environmental Performance
}

\author{
Fazal Ali Shaikh \\ Department of Economics \\ University of Sindh \\ Jamshoro, Pakistan
}

\author{
Muhammad Saeed Shahbaz \\ Department of Management Sciences \\ Shaheed Zulfikar Ali Bhutto Institute of \\ Science and Technology, Pakistan
}

\author{
Nasurullah Odhano \\ Department of Economics \\ University of Sindh \\ Jamshoro, Pakistan
}

\begin{abstract}
The aspects of sustainability and ecology have gradually become matters of significant concern within supply chain management processes. The aim of this study is to investigate the impact of the green supply chain on the environment and on operational performance. This study considers environmental management practices within firms, sustainable supply chain management practices relating to suppliers and customers, and environmentally conscious product and process design, by adopting a case-study approach and focusing on four major firms. The findings of this study reveal that the companies applying green supply chain management achieve better environmental performance but at an extra cost. Meanwhile, green practices provide improved customer satisfaction and attraction for retailers, distributors, and authorities.
\end{abstract}

Keywords-green supply chain; environmental performance; operational performance; case study

\section{INTRODUCTION}

The concepts pertaining to Supply Chain Environmental Management (SCEM) or Green Supply Chain Management (GSCM) are usually understood by the industry as the monitoring of the environmental performance of suppliers. However, the exercise of conscious trade has been gaining escalating consideration. A growing number of companies are pondering over the amalgamation of ecological practices in their policy designs [1]. Several motives are given to firms in order to become more environmental friendly. There are several motivational factors for introducing and applying the GSCM concept [2], such as market probabilities, trade efficiency, regulatory fulfillment, and risk management [3]. GSCM has a major role in confirming all the above elements [4]. Environmental impact may occur at all levels of a products' production chain and life time and GSCM comes out as a significant novel practice for enterprises to accomplish lowering their environmental impact $[5,6]$.

\section{LITERATURE REVIEW}

An empirical inspection of American buying supervisors regarding green buying showed that the fundamental motivating element for green buying is meeting the regulations. The effectiveness of environmental regulations on buying practices is expected to become the second most significant concern in the future [4]. Though the link between GSCM and firms' performance has been explored, the outcomes have not been decisive. There are two opposite theories regarding the connection between performance and environmental impact [7]. The first one proposes that environmental administration should just ensure the fulfillment of regulations and the second that environmental administration should be allowed to increase costs and investments in order to achieve better results. The impact of environmental parameters over the investment in terms of electricity use concluded that they are connected with the fall down in industrial manufacturing [8]. An optimistic connection between a firms' performance and environment friendly practices has been documented in [9]. The suggested framework and empirical outcomes hint to a positive impact of ecological practices to market share and cost. Recent research provided an understanding of the potential design of supply chain practices to improve ecoefficient performance. Smaller and localized firms were found to be easier to follow more eco-friendly approaches [10]. Connection with proprietors supports the acceptance and progress of creative environmental technologies [11], while dealing with clients and staff and cooperative R\&D leads towards better environmental performance. It is vague however whether GSCM leads to a positive or negative economical outcome. The actual long term economic impact is not easily assessed through considering a single factor such as short span profitability or sales performance [12]. Firms that reduce their environmental impact face an increased production cost but are also expected to gradually gain an increased market share [5].

Authors in [13] pointed out that environmental administration is in fact a creative environmental design for improving institutional performance. It has been indicated that an eco-efficient administration approach is capable to enhance a firm's functional performance [14]. A strong connection has been found between the meetings of objectives and staff contribution to environmental administration [7]. Returns on cost could be positively influenced when clients have a preference for the products/services of environment-friendly companies, while investment can be minimized via proactively handling environmental parameters that may cause hurdles. In addition, eco-friendly approaches may result to innovations that 
may provide a head-start advantage to firms, at least through a marketing point of view [15]. A positive connection between business communal performance and profit has also been documented [16]. It should be mentioned however that empirical studies regarding GSCM practices are scarce. The questions set in this study are: i) what are the effects of green supply chain over the environmental and functional performance of firms, and ii) what type of environmental administration practices are recommended to enhance the firm's eco-efficient performance. The framework of the study is developed to explore the connection between different GSCM practices [17]. There is a consensus in the literature that eco-friendly practices are a key factor in enhancing a firm's progress [18]. Previous studies highlighted several dimensions of GSCM [19-21] (Tables I-II).

TABLE I. ENVIRONMENTAL MANAGEMENT PRACTICES

\begin{tabular}{|c|}
\hline Environmental management practices within a firm \\
\hline Commitment to GSCM from senior and middle-level managers \\
\hline Total quality environmental management \\
\hline Environmental compliance and auditing program \\
\hline ISO 14000 certification \\
\hline GSCM practices relating to suppliers and customers \\
\hline Cooperation with suppliers for environmental objectives \\
\hline Company-wide environmental audits \\
\hline Environmental management for suppliers internal management \\
\hline Provide training to build supplier environmental management capacity \\
\hline Cooperation with customers for eco-design and cleaner production \\
\hline Cooperation with customers for green packaging \\
\hline Environmentally conscious product and process design \\
\hline Environmentally friendly raw materials \\
\hline Design of products for reduced consumption of material and energy \\
\hline Design of products for reuse, recycle, and recovery of materials \\
\hline Product design aiming to avoid or reduce the use of hazardous products \\
and/or their manufacturing process \\
\hline Optimization of the process to reduce solid/liquid waste and emission \\
\hline Use of reverse logistics \\
\hline
\end{tabular}

TABLE II. ENVIRONMENTAL AND OPERATIONAL PERFORMANCE CONSTRUCTS

\begin{tabular}{|c|}
\hline Environmental performance \\
\hline Reduction of solid/liquid waste and emissions \\
\hline Reduction of consumption for hazardous/toxic materials \\
\hline Reduction of frequency of environmental accidents \\
\hline Reduction of electricity usage \\
\hline Operational performance \\
\hline Cost savings and increased efficiency \\
\hline Product quality improvement \\
\hline Increase in market share \\
\hline New market opportunities \\
\hline Enhance employee motivation and performance \\
\hline Increase in sales \\
\hline
\end{tabular}

It has been found that encouragement from moderate scale directors, apart from manager's guidance, is also a key factor for fruitful GSCM application [22]. It has also been observed that GSCM may offer several advantages from cost reduction to increased public involvement (i.e. creating a trend) in the firm's policy and, thus an increased market share $[2,23]$. Thus, environmental concerns are becoming a visible ingredient of tactical patterns within firms [24]. Green advertising and environmentally friendly packaging are practices that may improve the environmental impact of the delivery chain [2,3]. To highlight the environmental influence of packaging, several countries have plans that aim to reduce the cost of wrapping [25]. It has been reported that standardized recyclable containers and fine merchandising designs minimize scarcity and recovery time making the product cost-friendly while also being eco-friendly [26]. Eco-efficient alert manufacturing and procedure patterns could integrate several such ideas, from reducing the consumption of materials and energy during the first stages of the production chain and implementing cleaner practices to minimize solid and liquid wastes to the utilization of eco-friendly logistics. Thus, the Return on Investment (ROI) has been considered a crucial dimension of GSCM [27].

\section{CASE STUDIES}

The public data regarding the GSCM practices of four major firms are considered as case studies. The firms were selected considering their market share, overall status, data availability and their overall environmental policy. Major firms were selected so that the principles and practices described may be considered as a future trend roadmap for smaller firms and policy makers.

\section{A. Eastman Chemical Company}

Eastman is devoted to durable supply chain administration practices and functional presentation improvement practices such as measuring brokers contributions, evolving substitutes strategies of supply, establish broker's solutions, enhancing packaging, utilizing recyclable packaging and encouraging supply chain networking, besides developing clients' solutions and managing material recovery [28, 29]. Eastman follows several environmental quantifiers and evolved the eco-efficient function practices by adding a greenhouse decrease objective, called TRI (Toxic Release Inventory). The design of Eastman's energy management policy has combined the demand for reasonable energy consumption with the demand to reduce production cost, e.g. by ensuring that the produced heat is used in more than one chemical processes. The firm also claims to apply efficient water administration practices and use recyclable materials in order to reduce waste [25].

\section{B. Westpac Bank, Australia}

The basic advantage of this firm is that it is working along with brokers and clients to enhance its manufacturing and products, e.g. in redesigning the packaging and in utilizing recyclable materials in several products. That process has brought enhancements in production and reduced logistic costs [30]. The company has declared a committance to comply with, or even exceed, the environmental legislation requirements in the areas it operates. The firm claims that has ensured reduced energy consumption and emissions in transportation, while it is a certified Carbon Neutral business [31].

\section{Coca Cola Enterprises}

The firm endorses the five strategic firm responsibility and sustainability CRS stress dimensions [28]. Coca Cola invested US \$34.8 million in 2008 on capital schemes concerning their three eco-efficient spotlight fields. In addition, they are evolving a cost-friendly evaluation process to focus on 
Common Reporting Standard (CRS) investments. The firm has highlighted certain goals in the field of energy consumption, water management, durable wrapping manufacture assortment, wellbeing, and diverse and comprehensive culture. It has decreased its entire carbon mark to $15 \%$ in 2020 in comparison to the 2007 baseline. The firm also follows a water sustainable function in which the usage of water is reduced and water neutral effectiveness is achieved. To decrease the influence of package related waste, the utilization of recyclable resources has been set as a major goal $[32,33]$. The company evaluated and claims it have reduced its carbon marks by utilizing a hybrid fleet, establishing a water durable function thus decreasing the ratio of water utilization and preserving more than 300 million liters of water, while it carried out a pilot study of entrenched stream footprint [19]. For reducing the influence of packaging materials the company stayed away from the use of around 31,000 metric tons of packaging materials, while $2.7 \%$ of the total quantity was recovered.

\section{Ernst and Young}

The firm has adopted the Sustainability Assurance Methodology and is a member of the China Financial Institution's Green Finance Committee. The provided services are eco-friendly and comply with the international standards and regulations. The company is specialized in providing tailored sustainability services to its clients such as consultations and funding regarding carbon emission reduction, supply chain management, risk management, etc. [34].

\section{DISCUSSION}

It is sufficient to say that in the days to come, carbon emissions will be considered tantamount to currency. Hence it is significant for international firms to take measures to control their supply chain and to estimate future costs and liabilities. Struggling against the inflation of energy and to decrease inhouse emissions approximately $40 \%$ of the firms have invested in reusable energy generation, which provides a firm grip over the cost of energy and also improves firm credibility and may even become profitable when selling the surplus of the produced electricity [30]. A growing number of traders are contending the launch of durable production to enhance their market share. A large proportion of participants account the sustainability as a chance for revenue growth. Credibility plus the name of the brand are the areas where prospects for sustainability and carbon concerned politics arise. Several prominent firms have to determine the full prospective and potential of advantages and profits in the account of sustainable chain administration [20]. A firm's reputation is harmed if its supply chain is found to be communally irresponsible [35]. Environmental friendly and sustainable practices on the other hand improve the reputation of a firm and, ultimately, its market share even with increased cost products [36].

Major firms devote significant resources towards improving their environmental impact, developing and establishing alternative techniques and approaches, reducing energy consumption, improving packaging, enhancing the use of reusable materials etc. Besides the prominent eco-friendly practices, other minor practices such as greenhouse excretion reduction and protection of logistics effectiveness have also been documented. Other frequently accomplished advantages are augmented effectiveness, reduced cost, enhanced risk administration, revenue growth, and credible reputation. It is significant for a company to have an ethical supply chain. The functional aspect that needs to amalgamate to the existing framework is enhanced risk administration and credibility [21]. The firms that include SSCM practices found a prominent impact on their environmental and functional performance. The limitation of this research was the convenience of sampling, so more and detailed case studies can be carried out.

\section{CONCLUSION}

This study was carried out with the aim to evaluate the association with SSCM practices in corporations in a functional manner besides the environmental one. A framework was established and an effort was made to validate the framework through case studies. More specifically the implementation of environmental practices in the supply chain administration along with the functional performance of organizations was evaluated. This study is meant to assist in implementing ecological or environmental supply chain administration practices in order to raise their competitiveness in the global market. The current most significant environmental issue is the carbon emission reduction. A major aim of this study is the exploration of the ecological dimensions of the supply chain administration and the course that must be followed in order to address this issue.

\section{REFERENCES}

[1] Q. Zhu, J. Sarkis, "Relationships between operational practices and performance among early adopters of green supply chain management practices in Chinese manufacturing enterprises", Journal of Operations Management, Vol. 22, No. 3, pp. 265-289, 2004

[2] G. C. Wu, "The influence of green supply chain integration and environmental uncertainty on green innovation in Taiwan's IT industry", Supply Chain Management, Vol. 18, No. 5, pp. 539-552, 2013

[3] C. I. Yang, S. Lien, "Governance mechanisms for green supply chain partnership", Sustainability, Vol. 10, No. 8, Article ID 2681, 2018

[4] Q. Zhu, J. Sarkis, K. H. Lai, "Confirmation of a measurement model for green supply chain management practices implementation", International Journal of Production Economics, Vol. 111, No. 2, pp. 261-273, 2008

[5] A. Longoni, D. Luzzini, M. Guerci, "Deploying environmental management across functions: The relationship between green human resource management and green supply chain management", Journal of Business Ethics, Vol. 151, No. 4, pp. 1081-1095, 2018

[6] K. W. Green Jr, P. J. Zelbst, J. Meacham, V. S. Bhadauria, "Green supply chain management practices: Impact on performance", Supply Chain Management, Vol. 17, No. 3, pp. 290-305, 2012

[7] S. Zailani, K. Jeyaraman, G. Vengadasan, R. Premkumar, "Sustainable Supply Chain Management (SSCM) in Malaysia: A survey", International Journal of Production Economics, Vol. 140, No. 1, pp. 330-340, 2012

[8] A. Touboulic, H. Walker, "Theories in sustainable supply chain management: A structured literature review", International Journal of Physical Distribution \& Logistics Management, Vol. 45, No. 1-2, pp. 16-42, 2015

[9] C. Busse, J. Meinlschmidt, K. Foerstl, "Managing information processing needs in global supply chains: A prerequisite to sustainable supply chain management", Journal of Supply Chain Management, Vol. 53, No. 1, pp. 87-113, 2017

[10] C. R. Carter, D. S. Rogers, "A framework of sustainable supply chain management: Moving toward new theory", International Journal of 
Physical Distribution \& Logistics Management, Vol. 38, No. 5, pp. 360 387, 2008

[11] S. Seuring, M. Muller, "From a literature review to a conceptual framework for sustainable supply chain management", Journal of Cleaner Production, Vol. 16, No. 15, pp. 1699-1710, 2008

[12] S. L. T. Berger, G. L. Tortorella, C. M. T. Rodriguez, "Lean supply chain management: A systematic literature review of practices, barriers and contextual factors inherent to its implementation", in: Progress in Lean Manufacturing, pp. 39-68, Springer, 2018

[13] T. Ng, M. Ghobakhloo, "What derives lean manufacturing effectiveness : An interpretive structural model", International Journal of Advanced and Applied Sciences, Vol. 4, No. 8, pp. 104-111, 2017

[14] A. B. Daud, A study on lean supply chain implementation in Malaysia's electrical and electronics industry: Practices and performances, MSc Thesis, Universiti Sains Malaysia, 2010

[15] Z. H. Zhang, B. F. Li, X. Qian, L. N. Cai, "An integrated supply chain network design problem for bidirectional flows", Expert Systems with Applications, Vol. 41, No. 9, pp. 4298-4308, 2014

[16] R. Z. R. M. Rasi, A. Abdekhodaee, R. Nagarajah, "Understanding drivers for environmental practices in SMEs: A critical review", IEEE International Conference on Management of Innovation \& Technology, Singapore, June 2-5, 2010

[17] M. S. Shahbaz, A. G. Kazi, B. Othman, M. Javaid, K. Hussain, R. Z. R. M. Rasi, "Identification, assessment and mitigation of environment side risks for Malaysian manufacturing", Engineering, Technology \& Applied Science Research, Vol. 9, No. 1, pp. 3851-3857, 2019

[18] M. Hasan, "Sustainable supply chain management practices and operational performance", American Journal of Industrial and Business Management, Vol. 3, No. 1, Article ID 26787, 2013

[19] S. Sohu, A. Halid, S. Nagapan, A. Fattah, I. Latif, K. Ullah, "Causative factors of cost overrun in highway projects of Sindh province of Pakistan”, IOP Conference Series: Materials Science and Engineering, Vol. 271, Article ID 012036, 2017

[20] US Resilience Project, Dow chemical: Strategies for supply chain security and sustainability, available at: https://usresilienceproject.org/ wp-content/uploads/2014/09/pdf-USRPDow_CS_012312.pdf, 2011

[21] R. Z. R. M. Rasi, R. Ramlan, T. Perera, N. J. Azmi, ““Enviroprenurial” value chain-a conceptual framework for Malaysian small and medium enterprises", International Conference on Industrial Engineering and Operations Management, Bali, Indonesia, January 7-9, 2014

[22] A. Hussain, R. M. Yusoff, M. A. Khan, M. L. M. Diah, M. S. Shahbaz, "The effect of transformational leadership on employee job performance through mediating role of organizational commitment in logistic sector of Pakistan", International Journal of Supply Chain Management, Vol. 8, No. 4, pp. 162-176, 2019

[23] M. S. Shahbaz, R. Z. R. M. Rasi, M. F. Bin Ahmad, S. Sohu, "The impact of supply chain collaboration on operational performance: Empirical evidence from manufacturing of Malaysia", International Journal of Advanced and Applied Sciences, Vol. 5, No. 8, pp. 64-71, 2019

[24] M. S. Shahbaz, R. Z. R. M. Rasi, M. H. Zulfakar, M. F. B. Ahmad, M. M. Asad, "Theoretical framework development for supply chain risk management for Malaysian manufacturing", International Journal of Supply Chain Management, Vol. 7, No. 6, pp. 325-338, 2018

[25] M. S. Shahbaz, S. Sohu, F. Z. Khaskhelly, A. Bano, M. A. Soomro, "A novel classification of supply chain risks: A review”, Engineering, Technology \& Applied Science Research, Vol. 9, No. 3, pp. 4301-4305, 2019

[26] M. S. Shahbaz, R. Z. R. Rasi, M. F. B. Ahmad, "A novel classification of supply chain risks: Scale development and validation", Journal of Industrial Engineering and Management, Vol. 12, No. 1, pp. 201-218, 2019

[27] M. S. Shahbaz, A. F. Chandio, M. Oad, A. Ahmed, R. Ullah, "Stakeholders' management approaches in construction supply chain: A new perspective of Stakeholder's theory", International Journal of Sustainable Construction Engineering and Technology, Vol. 9, No. 2, pp. 16-26, 2018
[28] Carbon Disclosure Project, Missing link: Harnessing the power of purchasing for a sustainable future, available at: https://www.bsr.org/ reports/Report-Supply-Chain-Climate-Change-2017.pdf, 2017

[29] EASTMAN, Corporate Environmental Policy, available at: www. eastman.com/Literature_Center/Misc/CorporateEnvironmentalPolicy.pdf

[30] Supply Chain Council, Supply chain operations reference model, Revision 11.0, Supply Chain Council, 2012

[31] Westpack Group, Westpac Group Environment Policy, available at: https://www.westpac.com.au/docs/pdf/aw/EnvironmentalPolicy.pdf

[32] Coca Cola European Partners, Environment policy: Our approach to environmental management, available at: www.cocacolaep.com/ assets/Sustainability/Documents/98d216dc36/Environment-Policy-Ourapproach-to-environmental-management.pdf, 2019

[33] CIPS, The global standard for procurement and supply, CIPS

[34] Ernst \& Young, Climate change and sustainability services, available at: https://www.ey.com/Publication/vwLUAssets/ey-climate-change-andsustainability-services-brochure-en/\$FILE/ey-climate-change-andsustainability-services-brochure-en.pdf

[35] S. Mubarik, N. Naghavi, M. F. Mubarak, "Governance-led intellectual capital disclosure: Empirical evidence from Pakistan”, Humanities and Social Sciences Letters, Vol. 7, No. 3, pp. 141-155, 2019

[36] M. S. Mubarik, C. Govindaraju, E. S. Devadason, "Human capital development for SMEs in Pakistan: Is the "one-size-fits-all" policy adequate", International Journal of Social Economics, Vol. 43 No. 8, pp. $804-822,2016$ 